\title{
Aspects of gene regulation in the diploid and tetraploid Odontophrynus americanus (Amphibia, Anura, Leptodactylidae)
}

\author{
Aurora M. Cianciarullo ${ }^{1}$, Paulo C. Naoum ${ }^{2}$, Álvaro L. Bertho ${ }^{3}$,Leonardo S. Kobashi', Willy Beçak ${ }^{l}$ and Maurilio J. Soares ${ }^{4}$
}

\begin{abstract}
Erythropoietic and hemoglobin DNA transcriptional activities were analyzed in the diploid and the tetraploid Odontophrynus americanus. Flow cytometric analyses of DNA, RNA and mitochondrial contents showed increased genic activity in both diploid and tetraploid animals during erythropoiesis in vivo elicited by pretreatment phenylhydrazine. Generally, higher values were seen in immature tetraploid erythroid cells. On the 10th day of recovery from anemia, large amounts of messenger RNA were found in both specimens. Based on the mitochondrial content, the tetraploid cells had more intense energy metabolism than the diploid cells. Diploid O. americanus had about three times more erythroid cells than tetraploid specimens, indicating that there were differences in the regulatory mechanisms of erythroid cells. Hematological parameters showed that tetraploid cells had 30\% more hemoglobin than the diploid, suggesting a regulatory mechanism of hemoglobin synthesis at the transcriptional level. Cytoplasmic inclusions resembling Heinz bodies were found in both types of cells. In the tetraploid cells they were previously found associated with RNA or RNP, suggesting that other regulatory system which controls the accumulation of nontranslated RNA transcribed in excess must be present. These differences at the physiological and molecular levels during erythropoiesis reinforce the hypothesis that speciation is occurring between diploid and tetraploid $O$. americanus.
\end{abstract}

\section{INTRODUCTION}

Ecological, biogeographical, and evolutionary processes encompass several categories of individual or populational responses that may affect the survival of a species or the rise of a new species (Endler, 1977). Genomic evolution by polyploidy is observed in plants (Stebbins, 1950) and animals (Beçak et al., 1966). When doubling of the entire chromosomal set occurs simultaneously, adaptive polymorphism will be fixed. This mechanism, which produces great genetic variability in a relatively fast manner, seems to have played an important role in the evolution of the lower vertebrates (Beçak, 1968; Beçak and Beçak, 1998). However, the question remains as to how gene expression is regulated in polyploid systems. Several hypotheses have been proposed but not fully demonstrated experimentally (Beçak and Pueyo, 1970; Cortadas and Ruiz, 1988; Ruiz and Brison, 1989; Álvares et al., 1998). In this context, Odontophrynus americanus, a South American frog, may provide a useful experimental genetic model. This species is a fossorial-terrestrial anuran and was the first reported example of a bisexual natural polyploid species of vertebrate (Beçak et al., 1966). Diploid and tetraploid cryptic specimens occur in allopatric populations of this frog in São Paulo State, Brazil. The aim of the present study was to examine erythrocyte maturation in vivo in a relatively synchronized polyploid system, to quantify some of the genic products synthesized during distinct stages of the erythropoiesis elicited by phenylhydrazine, and to correlate these results with gene regulation and speciation.

\section{MATERIAL AND METHODS}

Amphibians

Eight adult diploid, eight adult tetraploid $O$. americanus frogs (14-18 g) and four adult diploid Bufo ictericus toads (100-200 g) were collected in Botucatu (diploids) and São Roque (tetraploids), São Paulo State, Brazil.

\section{Induction of hemolytic anemia}

Four diploid and four tetraploid frogs were made anemic by subcutaneous injections of $0.5 \%$ phenylhydrazine hydrochloride (10 mg/body weight/day) in PBS solution, $\mathrm{pH} 7.0$, for three consecutive days (Cianciarullo and Meirelles, 1994). Immature erythroid cells were obtained from peripheral blood collected 5, 10, 15, 20, 30 and 50 days after the induction of anemia. The response to the drug was monitored using blood smears, stained with $0.5 \%$ new methylene blue in aqueous solution (Brecher, 1949), to vi-

\footnotetext{
${ }^{1}$ Laboratório de Genética, Instituto Butantan, Av. Vital Brazil, 1500, 05503-900 São Paulo, SP, Brasil. Send correspondence to A.M.C. Fax: +55-11-815-1505. E-mail: amcianciarullo@hotmail.com

${ }^{2}$ Laboratório de Hemoglobinas e Hemoglobinopatias, Departamento de Biologia, UNESP, São José do Rio Preto, Av. Cristóvão Colombo, 2265, 15054-000 São José do Rio Preto, SP, Brasil.

${ }^{3}$ Departamentos de Protozoologia and ${ }^{4}$ Ultra-estrutura e Biologia Celular, Instituto Oswaldo Cruz/FIOCRUZ, Av. Brasil, 4365 21045-900 Rio de Janeiro, RJ, Brasil.
} 
sualize immature forms of erythroid cells. Smears were counterstained with Rosenfeld's dye (Rosenfeld, 1947), to differentiate the cytoplasmic and nuclear acidophily and basophily. The distinct stages of erythropoiesis, as a function of time, were then determined by light microscopy.

\section{Flow cytometry}

Analyses of 15,000 cells for each normal and anemic blood sample from four diploid and four tetraploid frogs were made with an EPICS-751 flow cytometer (Coulter Electronics, USA), using the following parameters: cell size after red cell sphering (Mohandas et al., 1986), DNA and RNA content by acridine orange staining (Traganos et al., 1977) and mitochondrial content by rhodamine 123 staining (Darzynkiewicz et al., 1982). The intensity of red fluorescence emission, $\mathrm{F}_{>600 \text { (RNA, mitochondra), }}$ measured within a $600-650 \mathrm{~nm}$ band, and the intensity of green fluorescence emission, $\mathrm{F}_{>530(\mathrm{DNA})}$, measured within a $515-575 \mathrm{~nm}$ band, were obtained for cells excited at sharply focused $488 \mathrm{~nm}$ by an argon ion laser beam and recorded by separate photomultipliers. Controls were performed by incubating cell samples for $20 \mathrm{~min}$ at $37^{\circ} \mathrm{C}$ with $0.004 \%$ RNase diluted in PBS, pH 7.2, and by omission of the respective fluorochromes in each measurement.

\section{Total RNA extraction}

Blood of two normal and two anemic (10 days after anemia induction) adult Bufo ictericus toads was used as a control for the RNA synthesis, because of the great volume of blood these animals can provide. Total RNA extraction was performed according to Chomczynski and Sacchi (1987).

\section{Transmission electron microscopy}

Erythroid cells were fixed in a gradient concentration of 4 and $2 \%$ glutaraldehyde in $0.2 \mathrm{M}$ and $0.1 \mathrm{M}$ phosphate buffer, respectively (Brunner Jr. et al., 1975), postfixed in $1 \% \mathrm{OsO}_{4}$ diluted in the same buffer, contrasted en bloc with $2 \%$ uranyl acetate in aqueous solution, dehydrated in acetone series and embedded in Epon 812 resin. Thin sections were contrasted with lead citrate and examined in a Zeiss EM 109 transmission electron microscope.

\section{Determination of hematological parameters}

Classic clinical hematology procedures (Oliveira Lima et al., 1992) were applied to four normal diploid and tetraploid frogs. Red cells were counted in a Neubauer chamber using Hayen's liquid. Hematocrit was determined in order to establish the erythrocyte concentration (\%) in blood and to determine hematimetric values such as the mean corpuscular volume (MCV), mean corpuscular hemoglobin (MCH), and mean corpuscular hemoglobin concentration (MCHC).

\section{RESULTS}

\section{Recovery from hemolytic anemia}

Flow cytometry of blood samples from diploid and tetraploid $O$. americanus frogs before and after the induction of anemia revealed a small nonsignificant difference in the size of the erythroid cells in the two populations, with tetraploid cells usually being larger. Furthermore, immature cells were smaller than mature erythrocytes (Figure 1). These results were confirmed by light microscopy (data not shown).

The DNA, RNA and mitochondrial contents were quantified indirectly by measuring the incorporation of fluorescent dye into these structures (Figure 2A-C). DNA levels were usually proportional to the ploidy number. At all time points analyzed, the tetraploid cells had higher amounts of DNA compared to the diploid cells. However, the measurements were not uniform since they included cells in different stages of DNA synthesis and mitosis. Tetraploid cells showed a first DNA peak on the 10th day after the induction of anemia and a new, more pronounced peak at the 20th day, thus representing two distinct waves of erythropoiesis (Figure 2A). Diploid cells had a single peak 15-20 days after the induction of anemia and maintained these levels until the 30th day. After 50 days, the DNA content returned to normal levels in both diploid and tetraploid cells. The controls were negative (zero) for all measurements performed (data not shown).

The tetraploid cells produced two distinct RNA peaks, one on the 10th day and other on the 20th day after the induction of anemia, thus coinciding with the DNA peaks (Figure 2B). The diploid cells produced only one peak on the 10th day, but this was less intense than that of the tetraploid cells. Total RNA extraction of blood collected from the diploid Bufo ictericus obtained on the 10th day after the induction of anemia confirmed the data obtained by flow cytometry. A high RNA concentration in the $28 \mathrm{~S}$, $18 \mathrm{~S}$ and $5 \mathrm{~S}$ bands was found at this time (Figure 3: lane 2 ). The control, using blood samples from non-anemic toads, showed no detectable RNA under the same experimental conditions (Figure 3: lane 1).

The relative mitochondrial content showed that the tetraploid cells had a higher number of mitochondria (or larger ones) than the diploid cells at all time points (Figure 2C). A small increase in fluorescence was observed on the 10th day of recovery from anemia in both cell types, and this was maintained up to the 50th day.

The data obtained by flow cytometry and light microscopy were confirmed at the ultrastructural level, where a correlation between the erythrocyte maturation stage, the presence of cytoplasmic organelles and the variations in cell size was possible (Cianciarullo et al., 2000). The cyto- 


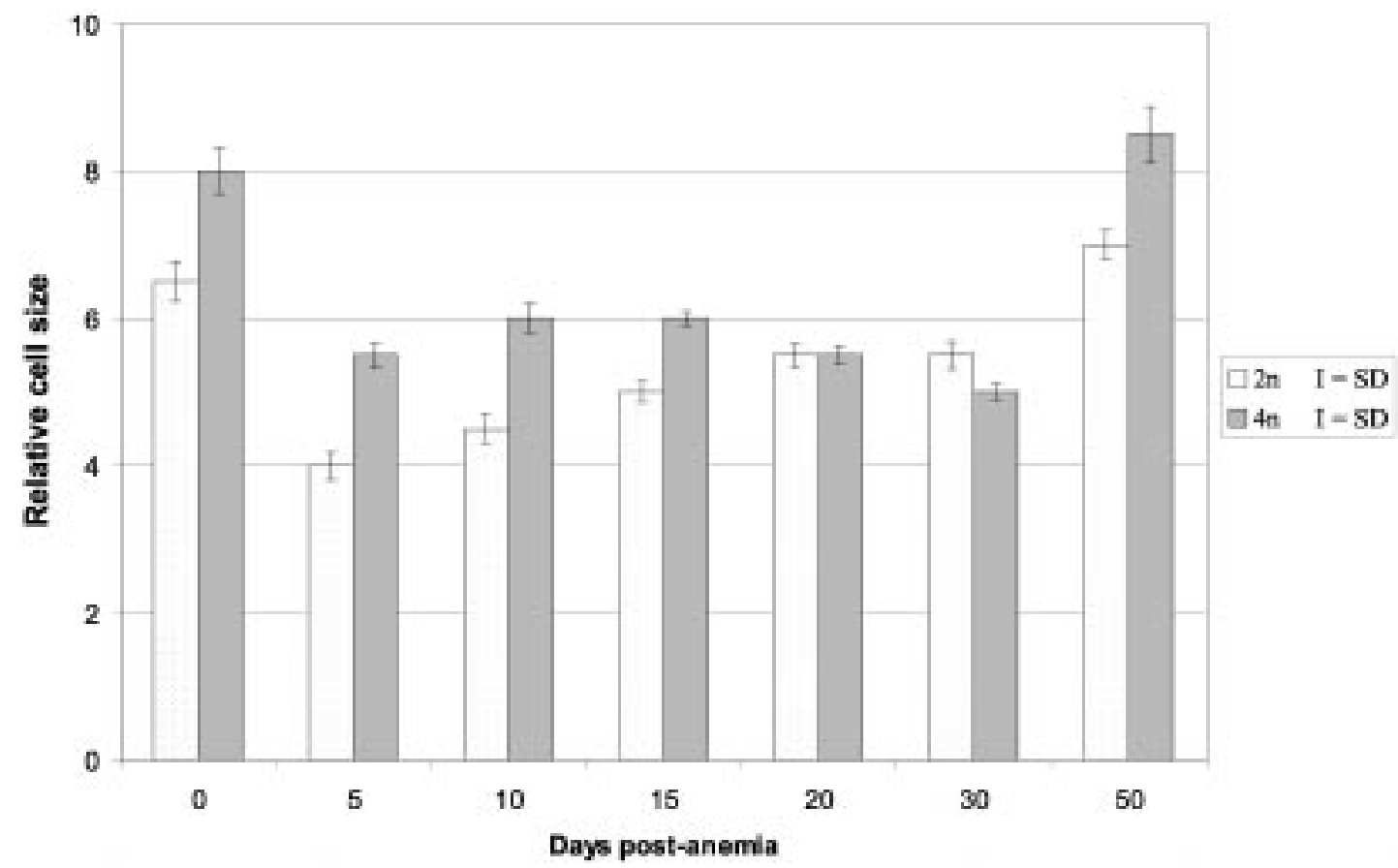

Figure 1 - Histogram of the relative cell size in spherical-made Odontophrynus americanus erythroid cells, during the different maturation stages of erythropoiesis. Arbitrary units; SD - standard deviation ( I ).

plasmic inclusions previously found in the tetraploid cells (Cianciarullo and Meirelles, 1994) were now detected in both diploid and tetraploid erythroid cells (Figures 4a,b).

\section{Hematological parameters}

The approximately two-fold higher hematocrit in diploid cells probably reflects the fact that the blood of diploid $O$. americanus contains about three times more erythroid cells than that of tetraploid organisms (Table I). The MCV was 50\% greater in tetraploid cells, whereas the total hemoglobin concentration was 50\% higher in the whole blood of the diploid animals. However, the $\mathrm{MCH}$ and MCHC measurements showed that tetraploid cells had 80 and $30 \%$ more hemoglobin per cell, respectively.

\section{DISCUSSION}

We examined the genic regulatory system that acts on erythropoietic cell production in vivo in diploid and tetraploid $O$. americanus frogs. A relatively synchronized system obtained by treating the frogs with phenylhydrazine hydrochloride helped to enhance erythropoiesis. This drug has been used to study erythrocyte maturation in amphibians and fishes (Cianciarullo et al., 1989, 1999; Spadacci Morena et al., 1991; Cianciarullo and Meirelles, 1994).

A follow-up of the in vivo erythropoiesis in diploid and tetraploid frogs by flow cytometry showed higher DNA, RNA and mitochondrial contents during this pro- cess, indicating increased genic activity in both diploids and tetraploids. The values were higher and distributed over a wider range in immature tetraploid erythroid cells, suggesting that gene activity in tetraploid $O$. americanus is more intense than in diploids during recovery from anemia. These data indicate that, because of their tetravalent state, the gene alleles in tetraploid animals may be more active under physiological stress than in diploid animals.

The DNA peak observed on the 20th day agrees with the results obtained by transmission electron microscopy, which showed very immature erythroid cells around the 30th day. Based on their ribosome content, these cells were classified as proerythroblasts and basophilic erythroblasts (Cianciarullo et al., 2000).

The RNA content of erythroid cells consisted predominantly of messenger RNA (mRNA), since the erythroid cells were not treated to analyze the ribosomal RNA (rRNA) or transfer RNA (tRNA), which are inaccessible without adequate previous treatment (Darzynkiewicz et al, 1975; Bauer and Dethlefsen, 1980). Thus, only singlestranded RNA was detected by our procedure. The RNA peaks on the 10th and 20th days of recovery from anemia corresponded to increased amounts of mRNA, most probably for globin synthesis.

The mitochondrial content reflects the state of energy metabolism in these cells. During erythropoiesis, the tetraploids showed more intense energy metabolism than diploid cells at all time points analyzed. Nevertheless, diploid cells also had an increased mitochondrial content, in- 
Figure 2 - Variations detected in the DNA (A), RNA (B), and mitochondrial (C) content during erythropoiesis in Odontophrynus americanus, measured as fluorescence intensity and days after anemia induction. Arbitrary units; SD - standard deviation (I).
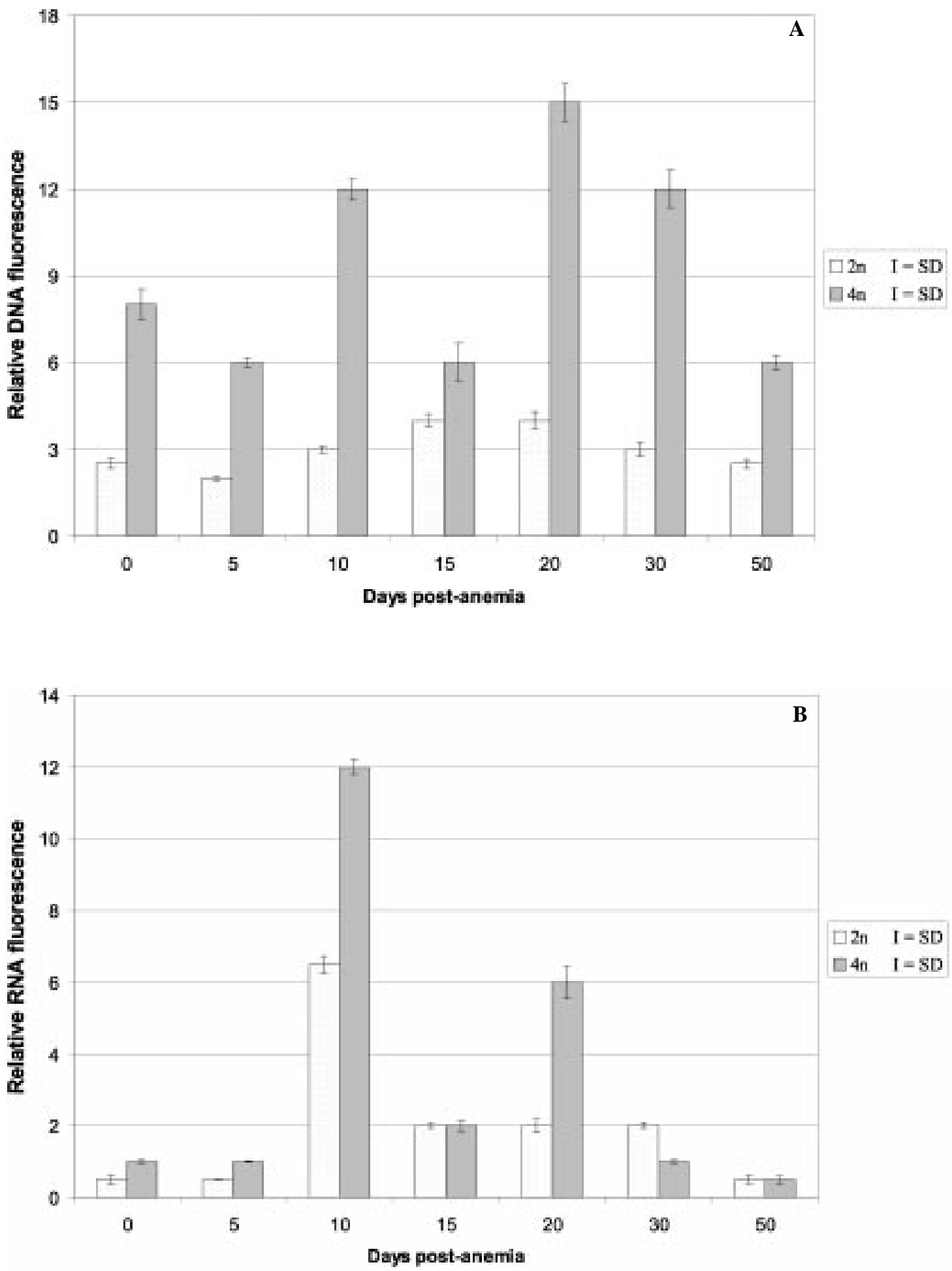


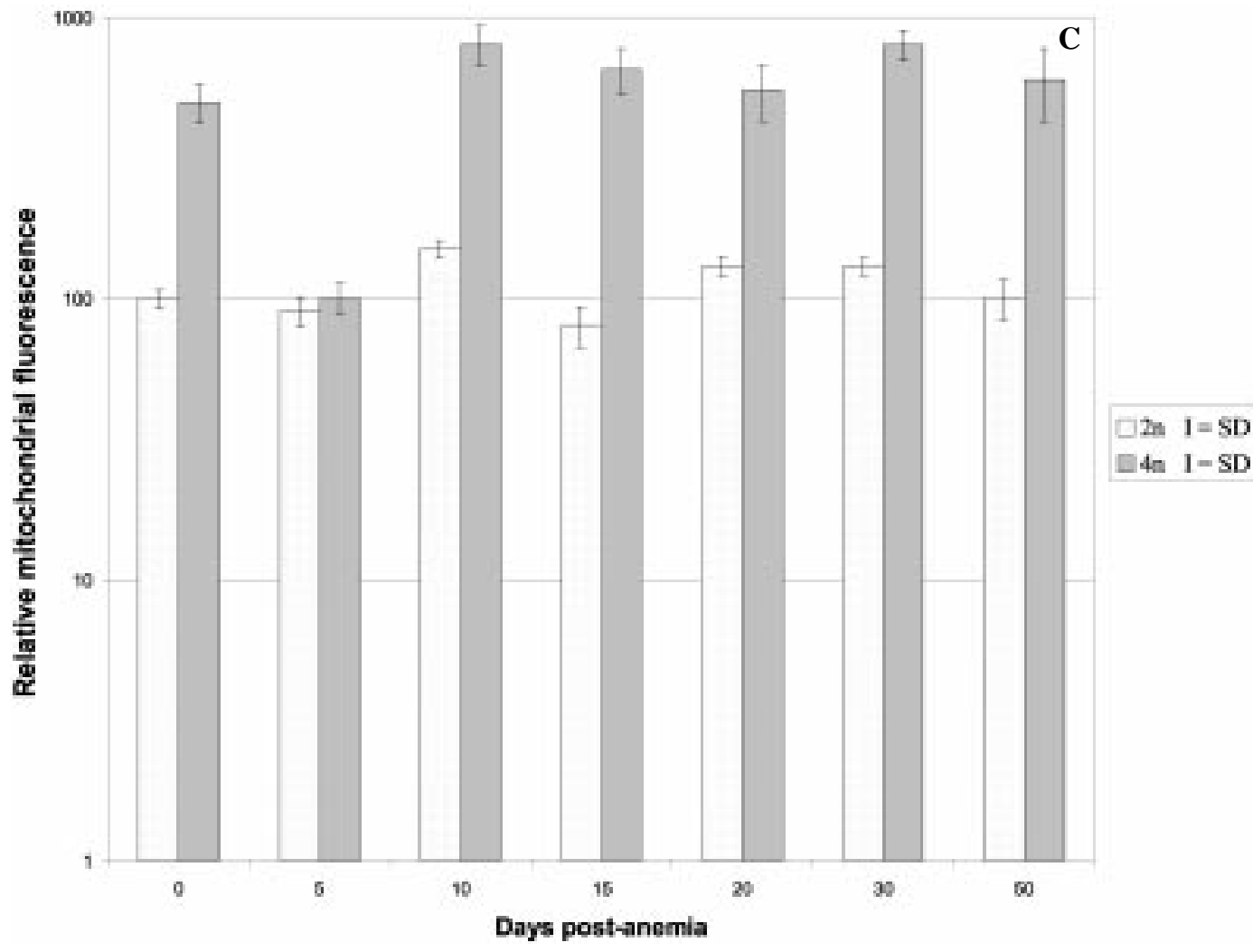

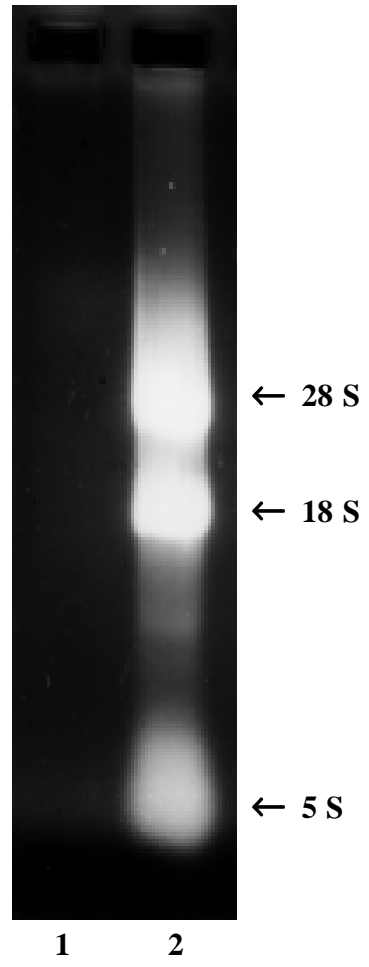

Figure 3 - Total RNA from Bufo ictericus blood cells. Blood samples were obtained from a non-treated animal used as control (lane 1) and an animal at the 10th day after hemolytic anemia induced by phenylhydrazine (lane 2). dicating that mitochondria may play an important role in the maturation of erythroid cells in these amphibians.

The DNA/RNA/hemoglobin ratio between diploid and tetraploid $O$. americanus was approximately $1: 2 / 1: 1.3 /$ $1: 1.3$, suggesting that gene expression was being regulated at the DNA transcriptional level. Apart from the diploidtetraploid $O$. americanus, another example of anuran cryptic species is found in the family Hylidae: the diploid Hyla chrysoscelis and the tetraploid Hyla versicolor tree frogs (Bogart and Wassermann, 1972). Measurements of several cytological characters in these Hyla species did not show 1:2 ratios as expected, further suggesting that the cytological factors analyzed were being regulated at the diploid level (Bachmann and Bogart, 1975).

The erythrocyte measurements summarized by Glomski et al. (1997) revealed ratios of 1:1.2 (length) and 1:1.1 (width) in diploid:tetraploid Hyla species, respectively. Our corresponding measurements were 1:1.1 (length) and 1:1.3 (width), respectively, for the diploid:tetraploid $O$. americanus (Cianciarullo et al., 2000), showing that erythrocyte size is not correlated with ploidy. The other hematological parameters could not be compared here because they were not described for the Hyla species. In some parameters, the tetraploid $O$. americanus had similar hematologic values to the diploid Bufo paracnemis toad, such as in the MCHC, which was $32.8 \%$ in toads (Naoum et al., 1986). 

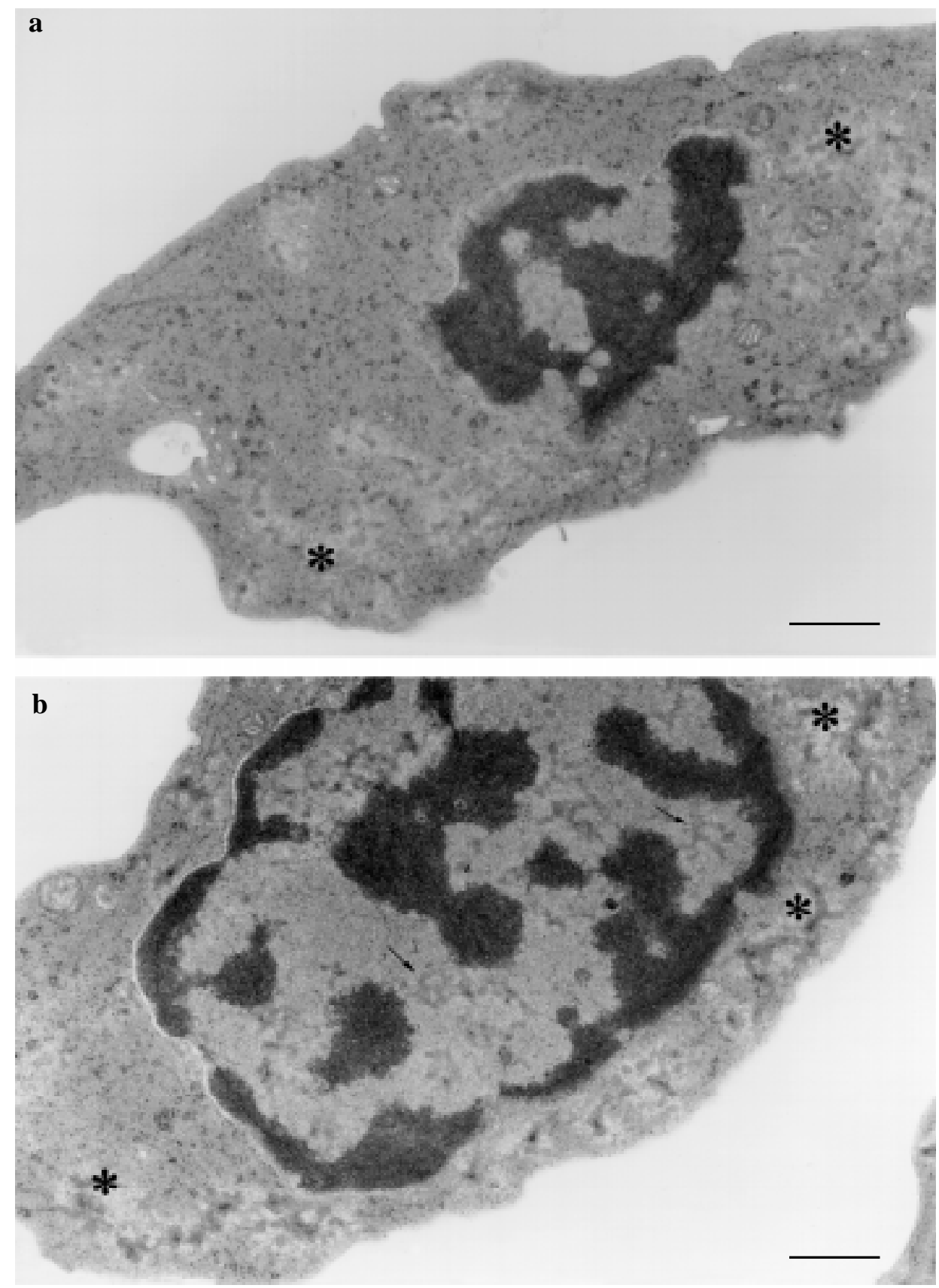

Figure 4 - Cytoplasmic inclusions (*) in maturing erythroid cells from diploid (a) and tetraploid (b) Odontophrynus americanus. Nuclear structures $(\rightarrow)$ similar to those found in the cytoplasm (b). Bars $=1 \mu \mathrm{m}$.

Diploid $O$. americanus had almost three times more erythroid cells than the tetraploids, but only $50 \%$ more total hemoglobin content. This fact appears to be due to the higher DNA content of the tetraploid cells. It also suggests a regulatory mechanism for maintaining the hemoglobin levels in the blood via a balance between the increased production of erythroid cells in diploid animals and lower levels of DNA transcription in tetraploid frogs.

The hematological data showed that $\mathrm{MCHC}$ was only $30 \%$ higher in the tetraploid cells. These data agree with morphometric analyses performed by transmission electron microscopy (Cianciarullo et al., 2000), which showed that tetraploid erythroid cells produce only $25-30 \%$ more ribosomes than diploid cells. These data also support the hypothesis that a regulatory system acts at the transcriptional level. Ruiz and Brison (1989) showed that methylation of ribosomal genes was increased in tetraploid genomes of adult $O$. americanus. If only $30 \%$ more ribosomes and 30\% more hemoglobin are synthesized by the tetraploid genome, DNA methylation levels could be the 
Table I - Hematological values for Odontophrynus americanus. The hematological determinations were made for blood samples from animals collected during autumn.

\begin{tabular}{|lcc|}
\hline & $\begin{array}{c}\text { Diploid } \\
(\mathrm{N}=4)\end{array}$ & $\begin{array}{c}\text { Tetraploid } \\
(\mathrm{N}=4)\end{array}$ \\
\hline Hematocrit $(\%)$ & $29.0(27.0-31.0)^{*}$ & $15.0(13.0-17.0)$ \\
RBC $\left(/ \mathrm{mm}^{3}\right)$ & 1,900000 & 700,000 \\
& $(1,600,000-2,100,000)$ & $(540,000-870,000)$ \\
Hemoglobin $(\mathrm{g} / \mathrm{dl})$ & $7.3(6.2-8.5)$ & $4.8(3.6-6.1)$ \\
MCV $\left(\mathrm{fl} \mathrm{or} \mu \mathrm{m}^{3}\right)$ & $155.0(143.0-167.0)$ & $225.0(203.0-247.0)$ \\
$\mathrm{MCH}(\mathrm{pg})$ & $38.0(34.7-40.9)$ & $69.0(65.8-71.6)$ \\
MCHC $(\mathrm{wt} / \mathrm{vol} \%)$ & $25.0(23.0-27.2)$ & $32.3(29.6-34.9)$ \\
\hline
\end{tabular}

*All values represent the mean and range (in parentheses) of each parameter. RBC, Red blood cells; fl, femtoliters; $\mathbf{p g}$, picograms; $\mathbf{M C V}$, mean cellular volume; $\mathbf{M C H}$, mean cellular hemoglobin; $\mathbf{M C H C}$, mean cellular hemoglobin concentration.

mechanism responsible for this genic regulation system, since the reduction of genic activity in these tetraploid amphibians does not result from the loss of ribosomal DNA (Schmidtke et al., 1976). Two other regulatory elements were suggested for the $O$. americanus model, including the presence of intergenic spacers (IGSs), i.e., enhancers of about $87 \mathrm{bp}$, and promoters of about 220/390 bp (Álvares et al., 1998). The role of these sequences in the regulation of rDNA activity needs to be confirmed.

The cytoplasmic inclusions detected here at the ultrastructural level, which are similar to the cytoplasmic inclusions associated with RNA or RNP and rich in the element phosphorus detected in the tetraploid cells in previous experiments described in detail by Cianciarullo and Meirelles (1994), have not been observed in other anuran species analyzed so far, or in other vertebrate classes under the same experimental conditions. In addition, nuclear structures similar to the cytoplasmic inclusions were equally intensely labeled by RNase-gold complexes and phosphorus detection. Rifkind and Danon (1965) described Heinz bodies (denatured hemoglobin) in rabbit erythroid cells, induced by phenylhydrazine treatment. It is possible that phenylhydrazine hydrochloride, the drug used to induce hemolytic anemia, interferes with the erythroid cells of these anurans, inducing the formation of Heinz bodies associated with RNA or RNP, as recently observed by Moenner et al. (1998) in human erythrocytes. On the other hand, the cytoplasmic inclusions should also represent excess ribosomal RNA (rRNA) synthesized in both diploid/tetraploid erythroid cells under physiological stress. This response may represent a regulatory system for the production of hemoglobin. Such regulation has been described in polyploid fishes, where hidden breaks are responsible for the accumulation of nontranslated rRNA transcribed in excess (Leipoldt and Engel, 1983). Further studies are necessary to elucidate these events.

We described erythropoiesis in vivo in diploid and tetraploid cryptic species of $O$. americanus frogs, and showed differences at the physiological and molecular levels. These data support the idea that speciation is in course in this population. The complexity of the mechanisms which coordinate the metabolic functions responsible for the survival of these tetraploids should be examined further, particularly in view of the similarity between amphibian and mammalian erythropoiesis (Cianciarullo et al., 1989).

\section{ACKNOWLEDGMENTS}

The authors thank Miss Marta A. Santiago for operational assistance with the flow cytometer and Conselho Nacional de Desenvolvimento Científico e Tecnológico (CNPq), Fundação Oswaldo Cruz (FIOCRUZ) and Fundação Butantan for the financial support. Publication supported by FAPESP.

\section{RESUMO}

A eritropoese e a atividade de transcrição de DNA de hemoglobina foram analisadas em Odontophrynus americanus diplóides e tetraplóides. Dados de conteúdo celular relativo de DNA, RNA e mitocôndrias obtidos por citometria de fluxo mostraram uma atividade gênica aumentada em ambos os animais durante a eritropoese in vivo estimulada por tratamento com fenilhidrazina, com valores maiores em eritrócitos tetraplóides imaturos. No décimo dia de recuperação da anemia foram encontradas grandes quantidades de RNA mensageiro em ambos espécimens. Com base no conteúdo mitocondrial, as células tetraplóides apresentaram um metabolismo energético mais intenso. O. americanus diplóides apresentaram três vezes mais células eritróides que os animais tetraplóides, caracterizando um mecanismo regulador da produção de células eritróides. Determinações hematológicas mostraram que as células tetraplóides contêm $30 \%$ mais hemoglobina que as células diplóides. Uma vez que $25-30 \%$ mais ribossomos estão presentes nas células tetraplóides, parece que um mecanismo regulador da síntese de hemoglobina esteja relacionado ao nível transcricional. Como as inclusões citoplasmáticas semelhantes a corpos de Heinz, porém associadas com RNA ou RNP, são encontradas em ambos os espécimens, é possível que outro mecanismo regulador esteja presente, similar ao das "hidden breaks" descritas em peixes poliplóides, acumulando rRNA transcrito em excesso e não traduzido. Estas diferenças em níveis fisiológicos e moleculares, detectadas durante a eritropoese, reforçam que divergências em nível de especiação estão em curso entre os $O$. americanus diplóides e tetraplóides.

\section{REFERENCES}

Álvares, L.E., Brison, O. and Ruiz, I.R.G. (1998). Identification of enhancer-like elements in the ribosomal intergenic spacer of Odontophrynus americanus $2 \mathrm{n}$ and $4 \mathrm{n}$ (Amphibia, Anura). Genetica 104: 41-44.

Bachmann, K. and Bogart, J.P. (1975). Comparative cytochemical measurements in the diploid-tetraploid species pair of hylid frogs Hyla chrysoscelis and H. versicolor. Cytogenet. Cell Genet. 15: 186-194.

Bauer, K.D. and Dethlefsen, L.A. (1980). Total cellular RNA content: correlation between flow cytometry and ultraviolet spectroscopy. J. Histochem. Cytochem. 28: 493-498.

Beçak, W. (1968). Poliploidia, polimorfismo genético e evolução nos vertebrados. Ciênc. Cult. 20: 202 (Abstract). 
Beçak, M.L. and Beçak, W. (1998). Evolution by polyploidy in Amphibia: new insights. Cytogenet. Cell Genet. 80: 28-33.

Beçak, W. and Pueyo, M.T. (1970). Gene regulation in the polyploid amphibian Odontophrynus americanus. Exp. Cell Res. 63: 448-451.

Beçak, M.L., Beçak, W. and Rabello, M.N. (1966). Cytological evidence of constant tetraploidy in the bisexual South American frog Odontophrynus americanus. Chromosoma 19: 188-193.

Bogart, J.P. and Wassermann, A.O. (1972). Diploid-polyploid cryptic species pairs: a possible clue to evolution by polyploidization in anuran amphibians. Cytogenetics 11: 7-24.

Brecher, G. (1949). New methylene blue as a reticulocyte stain. Am. J. Clin. Pathol. 19: 895-896.

Brunner Jr., A., Coiro, J.R.R., Mitsutani, C.Y., Santos, M.A.C. and Menezes, H. (1975). Ultrastructural aspects of mature Cyprinus carpio erythrocytes. Mem. Inst. Butantan 39: 157-168.

Chomczynski, P. and Sacchi, N. (1987). Single-step method of RNA isolation by acid guanidinium thiocyanate-phenol-cloroform extraction. Anal. Biochem. 162: 156-159.

Cianciarullo, A.M. and Meirelles, M.N.L. (1994). Comparative study of immature erythroid cells of the diploid Bufo ictericus and the tetraploid Odontophrynus americanus (Amphibia, Anura): ultrastructural cytochemical detection of nucleic acids and polysaccharides, and mapping of the element phosphorus. Cell Tissue Res. 278: 187-195.

Cianciarullo, A.M., Spadacci Morena, D.D., Morena, P. and Brunner Jr., A. (1989). Comparative ultrastructure of maturing toad (Bufo ictericus) and rabbit (Oryctolagus cuniculus) erythroid cells with regard to hemoglobin biosynthesis. Comp. Biochem. Physiol. 94A: 525-529.

Cianciarullo, A.M., Beçak, W. and Soares, M.J. (1999). Immunocytochemical mapping of the hemoglobin biosynthesis site in amphibian erythroid cells. Tissue \& Cell 31: 342-348.

Cianciarullo, A.M., Soares, M.J. and Beçak, W. (2000). Erythropoiesis in the diploid and tetraploid Odontophrynus americanus: an evolutionary approach in these cryptic species (Amphibia, Anura, Leptodactylidae). Comp. Haematol. Int. (in press).

Cortadas, J. and Ruiz, I.R.G. (1988). The organization of ribosomal genes in the diploid and tetraploid species of the genus Odontophrynus (Amphibia, Anura). Chromosoma 96: 437-442.

Darzynkiewicz, Z., Traganos, F., Sharpless, T. and Melamed, M.R. (1975). Conformation of RNA in situ as studied by acridine orange staining and automated cytofluorometry. Exp. Cell Res. 95: 143-153.

Darzynkiewicz, Z., Traganos, F., Staiano-Coico, L., Kapuscinski, J. and Melamed, M.R. (1982). Interactions of rhodamine 123 with living cells studied by flow cytometry. Cancer Res 42: 799-806.

Endler, J.A. (1977). Geographic Variation, Speciation, and Clones. Princeton
University Press, Princeton.

Glomski, C.A., Tamburlin, J., Hard, R. and Chainani, M. (1997). The phylogenetic odyssey of the erythrocyte. IV. The amphibians. Histol. Histopathol. 12: 147-170

Leipoldt, M. and Engel, W. (1983). Hidden breaks in ribosomal RNA of phylogenetically tetraploid fish and their possible role in the diploidization process. Biochem. Genet. 21: 819-841.

Moenner, M., Vosoghi, M., Ryazantsev, S. and Glitz, D.G. (1998). Ribonuclease inhibitor protein of human erythrocytes: characterization, loss of activity in response to oxidative stress, and association with Heinz bodies. Blood Cells Mol. Dis. 30: 149-164.

Mohandas, N., Kim, Y.R., Tycko, D.H., Orlik, J., Wyatt, J. and Groner, W. (1986). Accurate and independent measurement of volume and hemoglobin concentration of individual red cells by laser light scattering. Blood 68: 506-513

Naoum, P.C., Nagel, A.A. and Silva, F.S. (1986). Contribuição para a determinação dos valores hematológicos em Bufo paracnemis (Amphibia, Anura). Ciênc. Cult. 38: 883-892

Oliveira Lima, A., Soares, J.B., Greco, J.B., Galizzi, J. and Cançado, J.R. (1992). Hematologia. Métodos de Laboratório Aplicados à Técnica e Interpretação. Guanabara Koogan, São Paulo.

Rifkind, R.A. and Danon, D. (1965). Heinz body anemia: an ultrastructural study. I. Heinz body formation. Blood 25: 885-896.

Rosenfeld, G. (1947). Corante pancrômico para hematologia e citologia clínica. Nova combinação dos componentes do May-Grünwald e do Giemsa num só corante de emprego rápido. Mem. Inst. Butantan 20: 329-334.

Ruiz, I.R.G. and Brison, O. (1989). Methylation of ribosomal cistrons in the diploid and tetraploid Odontophrynus americanus (Amphibia, Anura). Chromosoma 98: 86-92.

Schmidtke, J., Beçak, W. and Engel, W. (1976). The reduction of genic activity in the tetraploid amphibian Odontophrynus americanus is not due to loss of ribosomal DNA. Experientia 32: 27-28.

Spadacci Morena,D.D., Matushima, E.R., Morena,P., Cianciarullo, A.M. and Brunner Jr., A. (1991). Ultrastructure of maturing fish (Oreochromis niloticus) and snake (Waglerophis merremii) erythroid cells with regard to hemoglobin biosynthesis. Comp. Biochem. Physiol. 100A: 949-955.

Stebbins, G.L. (1950). Variation and Evolution in Plants. Columbia University Press, New York.

Traganos, F., Darzynkiewicz, Z., Sharpless, T. and Melamed, M.R. (1977). Simultaneous staining of ribonucleic and deoxyribonucleic acids in unfixed cells using acridine orange in a flow cytofluorometric system. $J$. Histochem. Cytochem. 25: 46-56.

(Received December 9, 1999) 